\title{
Implikasi Lahirnya Undang-Undang Nomor 13 Tahun 2012 tentang Keistimewaan Daerah Istimewa Yogyakarta terhadap Status Hukum Pakualaman Ground di Kabupaten Kulon Progo
}

\author{
Novi Achmadiah Rahmahsari \\ Program Kenotariatan Fakultas Hukum Universitas Islam Indonesia \\ JL. Cik Ditiro No. 1 Yogyakarta \\ raisyazka@gmail.com
}

\begin{abstract}
This study intend to find out about how the application of UUK as seen from Implementation of UUK in registration rights of PAG's Land and next step about that in Kulon Progo regency. The results of this study is have been done a lot of improvement of policies related to privilege of DIY from colonial times until the enactment of UUK, That the registration and next step about registration rights of PAG's Land in Kulon Progo Regency still used the same procedure such as PP 24/1997. So it will be better to design a new system that is more efficient in handling PAG as soon as possible and provide education to people about the importance of having evidence right of land.
\end{abstract}

Keywords: Pakualaman Ground, Land, Law - Law Feature DIY

\begin{abstract}
Abstrak
Penelitian ini mengkaji permasalahan mengenai penerapan Undang-Undang Keistimewaan dilihat dari Implementasi UUK terhadap Pendaftaran Hak Atas Tanah Paku Alaman Ground beserta tindak lanjutnya di Kabupaten Kulon Progo. Hasil penelitian ini adalah bahwa telah dilakukan banyak perombakan kebijakan terkait keistimewaan DIY ini mulai dari jaman penjajahan hingga diterbitkannya UUK, Bahwa Pendaftaran dan tindak lanjut atas Pendaftaran HAak Atas Tanah PAG di Kabupaten Kulonprogo tetap menggunakan prosedur sesuai PP 24 Tahun1997. Sehingga akan lebih baik segera merancang sistem baru yang lebih efisien dalam menangani PAG serta memberikan edukasi kepada masyarakat tentang pentingnya memiliki tanda bukti Hak Atas Tanah.
\end{abstract}

Kata-kata Kunci: Pakualaman Ground, Pertanahan, Undang-Undang Keistimewaan DIY 


\section{Pendahuluan}

Pakualaman Ground (PAG) merupakan tanah di bawah kekuasaan Puro Pakualaman. Menurut penjelasan Pasal 32 ayat (32) Undang-Undang Nomor 13 Tahun 2012, yang dimaksud dengan "tanah kadipaten (pakualamanaat Grond)", lazim disebut Kagungan Dalem, adalah tanah milik Kadipaten.KadipatenPakualamanmerupakan bagian dariDaerah Istimewa Yogyakartayang sekarang menjadiKabupaten Kulon Progo.Sebelum terbentuknya Kabupaten Kulon Progo pada tanggal 15 Oktober 1951, wilayah Kulon Progo terbagi atas dua kabupaten yaitu Kabupaten Kulon Progo yang merupakan wilayah Kasultanan Ngayogyakarta Hadiningrat danKabupaten Adikarta yang merupakan wilayah Kadipaten Pakualaman. Perang Diponegoro di daerah Negaragung, termasuk di dalamnya wilayah Kulon Progo, belum ada pejabat pemerintahan yang menjabat di daerah sebagai penguasa. Pada waktu itu roda pemerintahan dijalankan oleh pepatih dalem yang berkedudukan di Ngayogyakarta Hadiningrat. Setelah Perang Diponegoro 18251830diwilayah Kulon Progo sekarang yang masukwilayah Kasultanan terbentuk empat kabupaten yaitu: ${ }^{1}$ a. Kabupaten Pengasih, tahun 1831; b. Kabupaten Sentolo, tahun 1831; c. Kabupaten Nanggulan, tahun 1851; d. Kabupaten Kalibawang, tahun 1855

Sejak masa kolonial di Yogyakarta telah berlaku 2 (dua) hukum agrarian, hukum adat dan hukum barat (burgelijke wetboek). Urusan hak tanah diatur dalam domein verklaring/Rijkblad Kasultanan tahun 1918 dan RijkbladPakualaman tahun 1918. Kekuasaan ini dinyatakan kembali dalam UU No. 3 Tahun 1950 tentang Pembentukan Daerah Istimewa Jogjakarta.

Keberadaan SG dan PAG diakui, baik oleh masyarakat luas maupun pemerintah. Terbukti jika pemerintah daerah hendak menggunakan tanah di wilayah Yogyakarta harus terlebih dahulu meminta izin kepada pihak Keraton atau Puro. Demikian juga kalangan pengusaha yang ingin berinvestasi di Yogyakarta.

Sementara masyarakat mengakui tanah itu ditandai dengan penerimaan Surat Kekancingan yang ada di masyarakat, menjelaskan bahwa status tanah yang ditempati adalah tanah magersari. Surat itu ditandatangani oleh Panitikismo atau pengelola tanah keraton. Lembaga panitikismo semacam di keraton tidak dijumpai di Paku Alaman dan saat ini baru diupayakan dibentuk. Pihak Paku Alaman mengakui justru yang mengetahui bidang dan luasan tanah Paku Alaman Ground adalah pihak Badan Pertanahan Nasional (BPN).

${ }^{1}$ http:/ / rheyndiaz2.blogspot.co.id/2014/01/eksistensi-sultan-ground-sg-dan.html diakses pada tanggal 18 Januari 2016. 


\section{LEx Renaissance No. 2 VOL. $1 \mathrm{JULI}$ 2016: $96-113$}

Permasalahan status hukum hak atas tanah Paku Alaman Ground (PAG) dari Puro Pakualaman dengan diberlakukannya UU No. 5 Tahun 1960 di Propinsi DIY serta berdasarkan Keppres No. 33 Tahun 1984 tanggal 9 Mei 1984 tentang Pelaksanaan Berlaku Sepenuhnya UU No. 5 Tahun 1960 di Propinsi Daerah Istimewa Yogyakarta tanggal 1 April 1984 masih memerlukan pengkajian. Hal ini dikarenakan secara yuridis keistimewaan Pakualaman Ground di bidang pertanahan belum mendapatkan legitimasi dalam peraturan perundang-undangan setelah dikeluarkan Keputusan Presiden Republik Indonesia Nomor 33 Tahun 1984. Terlebih lagi saat ini telah di undangkan pula menegenai keistimewaan Daerah Istimewa Yogyakarta dengan Undang - Undang Nomor 13 Tahun 2014.

Oleh karena itu sangat penting kiranya untuk mengetahui pengelolaan urusan pertanahan ini ketika telah dikeluarkannya Undang - Undang Nomor 13 Tahun 2014 tentang Keistimewaan Yogyakarta.

\section{Rumusan Masalah}

Berdasarkan latar belakang masalah yang telah diuraikan di atas, maka dapat dirumuskan permasalahan dalam penelitian ini: pertama, bagaimana proses konversi Hak Atas Tanah Paku Alaman Ground Baik bagi Paku Alaman sendiri maupun bagi Masyarakat di Kabupaten Kulon Progo berdasarkan ketentuan Hukum Tanah Nasional dan Undang Undang Nomor 13 Tahun 2012 tentang Keistimewaan Daerah Istimewa Yogyakarta? Kedua, bagaimanakah tindak lanjut proses pendaftaran Hak Atas Tanah bekas Paku Alaman Ground dari Kadipaten Paku Alaman kepada masyarakat yang memanfaatkan Paku Alaman Ground di Kabupaten Kulon Progo terkait dengan lahirnya Undang - Undang Nomor 13 Tahun 2012 Tentang Keistimewaan Daerah Istimewa Yogyakarta?

\section{Tujuan Penelitian}

Adapun tujuan penelitian ini, pertama: mengetahui proses legalisasi kepemilikan hak atas tanah paku alaman ground baik bagi pakualaman sendiri maupun bagi masyarakat di kabupaten kulon progo berdasarkan ketentuan hukum tanah nasional dan Undang Undang Keistimewaan Yogyakarta. Kedua, mengetahui tindak lanjut proses peralihan hak atas tanah bekas Paku Alaman Ground di Kabupaten Kulon Progo.

\section{Metode Penelitian}

Penelitian mengenai Implikasi Lahirnya Undang - Undang Keistimewaan Daerah Istimewa Yogyakarta Terhadap Kedudukan Hukum Pakualaman Ground Di Kabupaten 
Kulon Progo,pada hakekatnya adalah jenis penelitian hukum sosiologis. Jenis penelitian hukum sosiologis dilakukan dengan menelaah data sekunder yang diperoleh dari studi kepustakaan dan data primer yaitu data yang diperoleh secara langsung. ${ }^{2}$ Jenis penelitian ini menggunakan pendekatan doktrinal dan non doktrinal. Pendekatan doktrinal ${ }^{3}$ yang digunakan dalam penelitian ini adalah pendekatan perundang-undangan (Statue Approach) dan pendekatan konseptual (Conceptual Approach). Pendekatan non doktriner adalah jenis penelitian hukum social legal research. Jenis penelitian ini yaitu penelitian hukum social legal research, yaitu dengan mengkaji atau menganalisis data primer dan data sekunder yang berupa bahan-bahan hukum sekunder dengan memahami hukum sebagai perangkat peraturan atau norma-norma positif di dalam sistem perundang-undangan yang mengatur mengenai kehidupan manusia. ${ }^{4}$

Dengan perpaduan kedua metode pendekatan penelitian, yaitu doktrinal dan non doktrinal, penelitian ini diharapkan dapat memberi gambaran yang komprehensif terkait dengan substansi penelitian. Untuk mengkaji tentang permasalahan pertama dalam penelitian ini yaitu terkait regulasi, maka pendekatan doktrinal yang digunakan. Kemudian untuk mengkaji tentang implementasi, maka pendekatan non doktrinal yang digunakan. Sedangkan untuk mendapatkan rekonstruksi sebagaimana maksud dan tujuan di dalam permasalahan ketiga, maka perpaduan antara pendekatan doktrinal dan non doktrinal akan digunakan.

\section{Hasil Penelitian dan Pembahasan}

Proses Konversi Hak Atas Tanah Paku Alaman Ground Bagi Paku Alaman Dan Bagi Masyarakat di Kabupaten Kulon Progo Berdasarkan Ketentuan Hukum Tanah Nasional Dan Undang - Undang Nomor 13 Tahun 2012

UUPA adalah satu-satunya peraturan tentang agraria dan berlaku di NKRI, termasuk di DIY. Sementara, Pasal 1 UUK DIY menyatakan bahwa UUK adalah aturan khusus dari UU Pemerintahan Daerah, bukan aturan khusus dari UUPA. UUK tidak berlaku surut ke belakang karena pengakuan atas hak asal-usul yang dimaksud UUK adalah bentuk

2 Soerjono Soekanto, Pengantar Penelitian Hukum, UI Press, Jakarta, 1986, hlm.52.

3 Pendekatan doktrinal dapat menggunakan beberapa model pendekatan, yaitu: (1) Pedekatan perundangundangan (Statue Approach); (2) Pendekatan kasus (Case Approach); (3) Pendekatanhistoris. (Historical Approach); (4) Pendekatan perbandingan hukum negara lain (Comparative Approach); dan (5) Pendekatan konseptual (Conceptual approach). Lihat: Buku Pedoman Penulisan Tugas Akhir (TESIS), Program Magister Kenotariatan,Universitas Islam Yogyakarta, hlm.15-16.

${ }^{4}$ Paulus Hadisuprapto, Ilmu Hukum dan Pendekatannya, disajikan dalam Diskusi Panel "Refleksi Pendidikan Tinggi Hukum “, Semarang 17 Januari 2006. 
penghargaan dan penghormatan negara atas pernyataan berintegrasinya Kasultanan dan Kadipaten ke dalam NKRI untuk menjadi bagian wilayah setingkat provinsi dengan status istimewa (Pasal 4 huruf a). Artinya, klaim atas tanah-tanah SG dan PAG tidak mempunyai dasar hukum yang sah, karena SG/PAG termasuk tanah swapraja (feudal) yang sudah dihapuskan oleh Diktum IV UUPA. UUK juga melarang penghidupan kembali feodalisme (Pasal 4) dan penyalahgunaan wewenang oleh Gubernur (Pasal 16). Sehingga, UUPA sebagai aturan khusus dari UUD 1945 Pasal 33 ayat (3) adalah dasar hukum yang mengatur pertanahan di DIY saat ini. Bahkan, pemberlakuan kembali Rijksblad 1918 (aturan pemerintah kolonial) dalam tata hukum NKRI adalah anomali hukum. SG/PAG sudah dihapuskan oleh HB IX, PA VIII, beserta DPRD melalui Perda DIY No 3 Tahun 1984 yang merupakan pelaksanaan dari Keputusan Presiden No 33 Tahun 1984 dan UUPA.

Sebelum berlakunya Peraturan Pemerintah Nomor 10 Tahun 1961 juncto Peraturan Pemerintah Nomor 24 Tahun 1997 tentang Pendaftaran Tanah atau lebih dikenal dengan Cadaster Recht istilah ini telah dipakai oleh GouwGiok Siong dan Nyonya Soekahar Badwi, ${ }^{5}$ Boedi Harsono, ${ }^{6}$ dan Soedargo ${ }^{7}$ dalam arti pendaftaran tanah sebagaimana ditetapkan dalam pasal 19 ayat (2) Undang-Undang Pokok Agraria. Kadaster menurut Schermerhorn dan Van Steeinis ${ }^{8}$ dalam bukunya Hermanses ${ }^{9}$ yang tidak dipublikasikan adalah sebagai suatu badan pemerintah untuk meregister dan mengaministrasi keadaan hukum dari semua benda tetap dalam daerah tertentu termasuk semua perubahan-perubahan yang terjadi dalam keadaan hukum itu. (het kadaster is een everheiddsinstelling ter registrastie on administrasi van de rechtsteestandvan alle weizigeingen, die heirin in deleep der tijeen voorkomen).

Politik hukum pertanahan pada zaman penjajahan kolonial Belanda dengan azas Domein dan Agrarisch Wetnya, dimana siapa yang tidak dapat membuktikan tanah dengan tanda haknya dianggap tanah milik negara. Sehingga jelas bahwa hanya tanah-tanah yang sudah didaftarkan akan diberikan tanda bukti hak. ${ }^{10}$ Hak-hak penguasaan atas tanah dalam Undang-UndangNomor 5 Tahun 1960, memberikan kewenangan kepada Negara untuk berbuat sesuatu mengenai tanah yang dihaki, yaitu: a. hak menguasai dari negara misalnya

\footnotetext{
${ }^{5}$ Gouw Giok Siong/Soekahar Badwi SH., Tafsir Undang-Undang Pokok, Agraria,1963, cet.2, hlm.38-39.

${ }^{6}$ Mr. Boedi Harsono, Undang-Undang Pokok Agraria, 1961, hlm.158.

${ }^{7}$ Mr. Soedargo, Perundang-Undangan Agraria Indonesia, 1962 judul Bab XX

8 W Schermerhorn dan HJ Van Steeinis, Leer Boek der Landmet Kunde, cet.2, 1946, hlm.436.

${ }_{9}^{9}$ Pendaftaran tanah diIndonesia, Diktat Kulian Akademi Agraria Yogyakarta, 1990

${ }^{10}$ Tanda bukti hak atas tanah, untuk yang tunduk pada hukum golongan eropa/barat dengan hak eigendom, hak erfpacht dan hak opstal dan untk yang tunduk pada hukum adat dengan diberikan seperti hak yayasan, hak andarbeni dan hak tanah-tanah dengan hak-hak adat lainnya di Indonesia.
} 
memberi kewenangan untuk berbuat hal-hal yang disebut dalam pasal 2 UUPA; b. hak-hak atas tanah semuanya memberi kewenangan untuk menggunakan tanah yang dihaki, seperti yang disebut dalam pasal 4 UUPA; c. hak jaminan atas tanah memberi kewenangan kepada kreditur untuk menjual lelang tanah yang dijadikan jaminan untuk pelunasan piutang yang dijamin, jika debitur cidera janji, dengan mendahulu daripada kreditur-kreditur yang lain. Dalam hukum negara yang menggunakan azas accessie atau perlekatan dimana bangunan, tanaman yang berada diatas tanahserta kandungan mineral yang berada di dalam tanah merupakanbagian dari tanah, Sehingga perbuatan-perbuatan hukum mengenai tanah dengan sendirinya meliputi juga bangunan, tanaman yang berada di atas tanah serta kandungan mineral yang berada di dalam tanah ataukah apa yang disebut azas pemisahan horizontal dimana hukum tanahnya terpisah dengan benda-benda yang berada di atas tanah dan di dalam tanah, perbuatan hukum mengenai tanah tidak dengan sendirinya meliputi juga bangunan, tanaman yang berada ditas tanah dan kandungan mineral yang berada di dalam tanah. $^{11}$

Sejarah perkembangan hukum pertanahan/agraria diIndonesia sebelum kemerdekaan, Van Huls membagi kedalam 3 periode yaitu: ${ }^{12}$

1) Periode Pra Kadaster (1602-1837), periode KadasterLama (1837-1875) dan periode Kadaster Baru (setelah tahun1875). Pada perioede pra kadaster, dasar dari pendaftaran hak atastanah di Indonesia, dasar hukum dari pelaksanaan pendaftaran hakatas tanah adalah "Nedherlandsch Indisch Plaakatboek" (Buku Maklumat Hindia Belanda) yang dikeluarkan pada jaman "VecenigdeOost-Indisch Compagnie (VOC)" (Persekutuan Dagang Kompeni Hindia Timur) yang didirikan pada tahun 1602, VOC selainmenerima hak untuk berdagang sendiri di Indonesia daripemerintah di Negeri Belanda (Staten Generaal) juga menerima pula hak menjalankan kekuasaan kedaulatan di daerah yang dikuasainya dengan kekuatan senjata.

2) Periode KadasterLama (1837-1875), periode ini dikeluarkannya keputusanGubernur Jenderal Hindia Belanda (Gouverneur GeneralNedherlands-Indie) Staatblats 1837 Nomor 3 (S.1837. Nomor 3) tanggal 18 Januari 1837 yang menetapkan suatu instruksi bagi ahli ukur (Gouvernements Landmeters) di Jakarta, Semarang dan Surabaya sebagai awal pelaksanaan kadaster yang lebih terperincisesuai dengan pokok-pokok penyelenggaraan kadaster dalam arti modern dan;

3) Periode Kadaster Baru (1875-1960), periode inidikeluarkannya peraturan untuk penyusunan kadaster barudiantaranya: Staatblats 1875 Nomor 183 juncto Staatblats 1879Nomor 164) tentang Alagemene Voorschriffen de Kadasterale Metingen in Ned-

${ }^{11}$ Hukum pertanahan yang bersumber pada Kitab Undang-Undang Hukum Perdata (pasal 500) dan hukum pertanahan di Singapura (pasal 4 Land Tittle Act 1970) misalnya menggunakan azas accessie. Hukum pertanahan adat menggunakanazas pemisahan horizontal. Dengan demikian juga hukum pertanahan/agraria(UUPA) yang berlaku hingga sekarang yang didasarkan pada hukum adat

${ }^{12}$ Mr. C.G van Huls, Uitbreining van de Taak van de Diesnt van het Kadaster, 1952, hlm. 60. 
Indie (ketentuan-ketentuan umum mengenai pengukuran-pengukuran kadaster di Indonesai).

Sejarah pengaturan macam-macam hak penguasaan atas tanah di Indonesia yang ada dalam hukum pertanahan/agraria memiliki 3 (perangkat) hukum tanah. Ketiga perangkat hukum tersebut mempunyai kebhinekaan sruktur perangkat hukum yang berlaku bersamaan, masing-masing mengenai kelompok tanah-tanah yang memperoleh status yang berbeda. Kelompok peraturan-peraturan hukum yang mengatur hak-hak penguasaan atas tanah sebagai lembaga hukum, yaitu yang menetapkan dan yang mengatur macam-macam hak penguasaan atas tanah yang ada dalam hukum pertanahan/agraria yang bersumber dari: 1) Bersumber pada Kitab Undang-undang Hukum Perdata (KUHPerdata), lebih dikenal dengan macam-macam hak hak eropa atau hak barat seperti hak eigendom hak erfpacht dan hak opstal yang semuanya didaftar dengan tanda bukti hak; 2) Hukum dari bekas swapraja, lebih dikenal dengan hak-hak bekas kerajaan dan untuk tiap-tiap daerah mempunyai nama yang berbeda-beda seperti: Bekas Swapraja di Banyumas, Madiun dan Kediri dengan nama desa-desa "perdikan", diYogyakarta (Risjksblad Kasultanan Tahun 1926 Nomor 13) dan Solo (Rijksblad Kesunanan Tahun 1938 Nomor 14) dengan "hak-hak konversi", di Medan (Peraturan Gemeente/Kotapraja Medan) dengan hak "grant sultan” bagi tanah-tanah bekas Sultan Delli, Kutai Penguasaan atas tanah diatur dalam peraturan pelaksanaannya yang bernama Undang-Undang Maharaja Nanti atau lebih dikenal dengan Undang-Undang Beraja Niti, yang terdiri dari 164 pasal. Undang-undang tersebut diberlakukanpada jaman pemerintahan Sultan Aji Muhammad Sulaiman(1845-1899) dengan pemberian hak "Pengoempoean", "Limpah Kemoerahan”, dan lain-lain, dan; 3) Hukum pertanahan/agraria adat, dimana konsepsinya didasarkan atas kuatnya hubungan bathin dengan sumber daya tanah dan alamnya sebagai hak milik yang meletakan hukum adat sebagai sumber utamanya, mengandung rumusan dan mempuyai ciri-ciri landasan "komunalistik religus", memungkinkan penguasaan tanah secara individual, dengan hak-hak atas tanah yang bersifat pribadi, sekaligus mengandung kebersamaan.

Pengaturan hal-hal mengenai penetapan pemegang hak atas tanah sebelum UUPA adalah hukum perdata, untuk subyek hak dari hak-hak eropa atau hak-hak barat dan golongan tertentu dengan sistem pendaftaran hak yang diatur dalam Kitab Undang-undang Hukum Perdata dengan sistem negatif, sedangkan dalam hal peralihan hak atas tanah mengenal duamacam azas yaitu azas "memo plusjuris" dan azas itikad baik, dimana azas memo plusjuris adalah azas dalam pengalihan hak yang berasal dari Hukum Romawi, menurut azas ini orang tidak dapat mengalihkan hak yang melebihi hak yang ada padanya (memo plujuris um transfer potest qua ipse habed). Tujuan dariazas memo plusjuris adalah 
melindungi pemegang hak yang sebenarnya terhadap tindakan orang lain yang mengalihkan haknya tanpa sepengetahuannya. Berhubung dengan itu, di negara-negara dimana berlaku azas tersebut hanya dapat diselenggarakan sistem pendaftaran hak yang negatif. ${ }^{13}$ Hukum tanah kita sekarang ini menggunakan asas hukum adat, yaitu: ${ }^{14}$

1) Sebelum Undang-Undang Nomor 5 Tahun 1960 tentang Peraturan Dasar Pokok-Pokok Agraria (UUPA) berlaku diIndonesia berlaku 3 (perangkat) hukum tanah. Mengingatbahwa UUPA atau Undang-Undang Nomor 5 Tahun 1960 disusun dan diundangkan dalam rangka mengadakan unifikasihukum tanah, maka pasal-pasal yang mengandung penerapanasas Accersie harus dianggap sebagai "tidak berlaku" lagi. Bahkan Hasni menyatakan secara tegas, dalam kesimpulannya yang menyatakan bahwa bahwa pada asasnya, ada pemisahan antara tanah dan bangunan yang berdiri di atasnya (asas pemisahan horizontal), yang menyatakan bahwa hukum yang berlaku terhadap tanah tidak sendirinya berlaku juga terhadap bangunan yang berdiri diatasnya. "Tanah tunduk pada hukum tanah", sedangkan pengaturan soal bangunan termasuk hukum perutangan.

2) bahwa kepemilikan atas tanah tidak dengan sendirinya meliputi juga pemilikan bangunan yang ada di atasnya. "Barang siapa yang membangun, dialah pemilik bangunan yang dibangun".

Hal tersebut sejalan dengan apa yang dikemukakan oleh Subekti yang menyatakan bahwa B.W dalam tanah menganut apa yang dinamakan "asas vertical”, sedangkan Hukum Adat menganut "asas horizontal" . Menurut asas vertikal, maka hakmilik atas sebidang tanah meliputi benda-benda yang berada diatasnya (bangunan). Karena itu maka azas vertikal itu juga dinamakan asas "absorpsi” (artinya: menyedot segala apa yang berada di atasnya). Sedangkan menurut asas horizontal hak milik atas sebidang tanah tidak meliputi bangunan yang ada diatasnya. Sedangkan dalam hukum tanah nasional yang akan datang, sudah disepakati oleh para sarjana hukum kita, untukmenganut asas horizontal, tetapi dengan memungkinkan pengecualian-pengecualian. ${ }^{15}$ Pendapat Subekti tersebut, sejalan dengan apa yang tertuang dalam Ketentuan Pasal5 UUPA, yang menjadikan Hukum Adat sebagai dasar dari hukum agraria. Pasal 5 UUPA menyatakan bahwa Hukum Agraria yang berlaku atas bumi, air dan ruang angkasa ialah hukum adat, sepanjang tidak bertentangan dengan kepentingan nasional dan negara, yang berdasarkan atas persatuan bangsa,dengan sosialisme Indonesia serta dengan peraturan-peraturan yang tercantum dalam UUPA dan

${ }^{13}$ Mr. H.E.A. Volmar, Inleiding tot de studie van het Nedherlands Bergerlijk Recht,cet.2, 1950, hlm.175

${ }^{14}$ Hasni, Hukum Penataan Ruang dan Penatagunaan Tanah Dalam kontek UUPA - UUPR - UUPLH, Jakarta, Rajawali Pers, 2008, hlm. 329

15 Subekti, Perbandingan Hukum Perdata, Jakarta, PT. Pradnya Paramita, 1992, H. 29-30 
dengan peraturan perundang-undangan lainnya, segala sesuatu dengan mengindahkan unsur-unsur yang bersandar pada hukum agama.

Dalam Penjelasan Umum Angka Romawi III, angka 1 disebutkan mengenai pertimbangan mengapa UUPA menjadikan dasar Hukum Adat dari Hukum Agraria, yaitu salah satunya bahwa rakyat Indonesia sebagian terbesar tunduk pada hukum adat, maka hukum agraria yang baru tersebut akan didasarkan pula pada ketentuan-ketentuan hukum adat itu, sebagai hukum yang asli, yang disempurnakan dan disesuaikan dengan kepentingan masyarakat dalam Negara.

Oleh karenanya masyarakat harus menyadari bahwa dirinya mempunyai hak atas tanah dan hak itu dijamin UUPA. Adapun cara memperjuangkan / mempertahankan hak di tingkat perorangan dan kelompok sebagai berikut:

1) Bagi masyarakat yang menempati tanah turun-temurun dan belum memperoleh hak milik tidak perlu mengurus surat ijin (serat kekancingan) ke Panitikismo untuk mendapatkan hak menempati/memanfaatkan baik itu bernama magersari, ngindhung, anggadhuh, dan angganggo. Mengurus magersari dan sebagainya berarti mengakui SG/PAG berdasarkan Rijksblad 1918 yang telah dihapuskan sejak 1984, sehingga masyarakat sama saja kehilangan hak atas tanah. Sebaliknya, masyarakat justru perlu melakukan pendaftaran tanah yang telah ditempatinya turun-temurun tersebut ke BPN agar mempunyai hak milik, bukan sekedar hak pakai/hak guna bangunan. Jika maka menjadi kewajiban pemerintah untuk memberikan hak milik sebagaimana amanat TAP MPR RI No 9 tahun 2001 dan UUPA beserta aturan pelaksanaannya..

2) Bagi masyarakat yang sudah memiliki sertifikat hak milik tidak perlu menyerahkan sertifikat hak miliknya kepada tim ajudikasi pertanahan Keraton/Pemerintah Daerah/Pemerintah Desa meskipun alasannya untuk diperbaharui, karena akan status hak milik dapat diubah menjadi hak pakai jika asal-usul tanah yang dimilikinya dianggap sebagai SG/PAG.

3) Bagi masyarakat yang mempunyai Hak Guna Bangunan/Hak Pakai agar memperpanjang haknya dengan status tetap di atas tanah negara atau meningkatkan haknya menjadi hak milik. Apabila terjadi perubahan status dari HGB di atas tanah negara menjadi HGB di atas tanah SG/PAG, maka masyarakat perlu menyadari bahwa itu merupakan pelanggaran hukum.

Sebelum kita membahas mengenai cara Pakualaman mendaftarkan tanah yang merupakan milik dari pakualaman maka seharusnya kita lihat terlebih dahulu bahwa Pakualaman sendiri adalah badan hukum yang diberikan status sebagai badan hukum berdasarkan Undang - Undang Nomor 13 Tahun 2012 Tentang Keistimewaan Yogyakarta. Sehingga pendaftaran kepemilikan atas tanahnya seharusnya mengacu pada UUPA dan juga Peraturan Pemerintah No. 38 Tahun 1963 tentang Penunjukan Badan-Badan Hukum Yang Dapat Mempunyai Hak Milik Atas Tanah (“PP No. 38/1963”). Berdasarkan Pasal 1 PP No. 38/1963, badan-badan hukum yang dapat mempunyai tanah hak milik, yaitu: a. Bank-bank yang 
didirikan oleh Negara (selanjutnya disebut Bank Negara); b. Perkumpulan-perkumpulan Koperasi Pertanian yang didirikan berdasar atas Undang-Undang No. 79 Tahun 1958 (Lembaran-Negara Tahun 1958 No. 139); c. Badan-badan keagamaan, yang ditunjuk oleh Menteri Pertanian/Agraria, setelah mendengar Menteri Agama; d. Badan-badan sosial, yang ditunjuk oleh Menteri Pertanian/Agraria, setelah mendengar Menteri Kesejahteraan Sosial.

Dengan memperhatikan PP tersebut maka muncul pertanyaan Pakualaman termasuk ke dalam Badan Hukum yang mana. Akan tetapi terkait dengan hal tersebut maka para pakar Politik Hukum Agraria Nasional berpendapat bahwa Pakualaman dan Kesultanan merupakan Badan Hukum Khusus yang merupakan Cagar Budaya Berdasarkan Undang Undang Nomor 13 Tahun 2012 sehingga dapat pula memiliki hakmilik atas tanah.

Dalam Pasal 19 UUPA dinyatakan bahwa persyaratan untuk pendaftaran tanah bagi Badan Hukum adalah sebagai berikut: 1. Formulir permohonan yang sudah diisi dan ditandatangani pemohon atau kuasanya di atas materai cukup; 2. Surat Kuasa apabila dikuasakan; 3. Fotocopy identitas (KTP) pemohon dan kuasa apabila dikuasakan, yang telah dicocokkan dengan aslinya oleh petugas loket; 4. Fotocopy Akta Pendirian dan Pengesahan Badan Hukum yang telah dicocokkan dengan aslinya oleh petugas loket; 5. Bukti perolehan tanah/Alas Hak; 6. SK Penunjukan badan hukum yang dapat memperoleh Hak Milik dari Kepala Badan Pertanahan Nasional; 7. Surat ijin untuk memperoleh Hak Milik dari Kepala Badan Pertanahan Nasional; 8. Foto copy SPPT PBB Tahun berjalan yang telah dicocokkan dengan aslinya oleh petugas loket; 9. Melampirkan bukti SSP/PPh sesuai dengan ketentuan.

Kemudian untuk masyarakat dapat mendaftarkan hak atas tanahnya dengan persyaratan: 1. Formulir permohonan yang sudah diisi dan ditandatangani pemohon atau kuasanya di atas materai cukup; 2. Surat Kuasa apabila dikuasakan; 3. Fotocopy identitas (KTP, KK) pemohon dan kuasa apabila dikuasakan, yang telah dicocokkan dengan aslinya oleh petugas loket; 4. Asli Bukti perolehan tanah/Alas Hak; 5. Asli Surat-surat bukti pelepasan hak dan pelunasan tanah dan rumah (Rumah Gol III) atau rumah yang dibeli dari pemerintah; 6. Foto copy SPPT PBB Tahun berjalan yang telah dicocokkan dengan aslinya oleh petugas loket, penyerahan bukti SSB (BPHTB) dan bukti bayar uang pemasukan (pada saat pendaftaran hak); 7. Melampirkan bukti SSP/PPh sesuai dengan ketentuan.

Sedangkan Prosedur menurut PP No. 24 Tahun 1997: 1) Diajukan secara individual atau massal oleh pihak yang berkepentingan [Pasal 13 (4)], yaitu pihak yang berhak atas bidang tanah yang bersangkutan atau kuasanya, Permen Agraria/Kep BPN 3/1997 pihak yang berkepentingan adalah pemegang hak dan pihak lain yang mempunyai kepentingan 
atas bidang tanah; 2) Pembuatan Peta Dasar Pendaftaran (Pasal 15 dan 16), menjadi dasar pembuaan peta pendaftaran. Untuk kepentingan ini BPN menyelenggarakan pemasangan, pengukuran, pemetaan dan pemeliharaan titik2 dasar teknik nasional di setiap kabupaten/kota; 3) Penetapan Batas Bidang-Bidang Tanah (Pasal 17-19), dilakukan dengan memperhatikan batas 2 bidang tanah yang telah terdaftar dan SU atau GS yang bersangkutan, jika ada yang tidak sesuai dengan keadaan yang sebenarnya maka sedapat mungkin disetujui oleh pemegang hak yang berbatasan. Guna penetapan batas2, maka BPN juga membuat berita acara mengenai dilakukannya pengukuran; 4) Pengukuran dan Pemetaan Bidang Tanah dan Pembuatan Peta Pendaftaran (Pasal 20); 5) Pembuatan Daftar Tanah (Pasal 21), bidang tanah yang sudah dipetakan atau diberi nomor pendaftarannya dibukukan dalam daftar tanah; 6) Pembuatan SU (Pasal 22), untuk keperluan pendaftaran haknya; 7) Pembuktian Hak Baru (Pasal 23), HAT baru dengan : penetapan pemberian hak oleh pejabat atau asli akta PPAT, HPL dengan penetapan pemberian HPL oleh pejabat yang berwenang, Tanah Wakaf dengan akta Ikrar Wakaf,Hak Milik Atas Satuan Rumah Susun dengan akta pemisahan, HT dengan APHT; 8) Pembuktian Hak lama (Pasal 24 n 25), berasal dari konversi hak, dibuktikan dengan bukti tertulis, keterangan saksi, jika tidak tersedia alat pembuktian yabng lengkap dapat dilakukan dengan pernyataan penguasaan fisik selama 20 th berturut2, dengan syarat penguasaan dilakukan dengan itikad baik secara terbuka dikuatkan oleh kesaksian orang yang dapat dipercaya (umumnya oleh lurah), Tidak ada permasalahan dalam hal penguasaan baik sebelum maupun setelah pengumuman; 9) Pengumuman Hasil Penelitian Yuridis dan Hasil Pengukuran (Pasal 26-27), jika ada pihak yang berkeberatan, maka disarankan untuk menyelesaikan secara musyawarah, jika tidak berhasol, maka diselsaikan di pengadilan; 10) Pengesahan Hasil Pengumuman (Pasal 28), disahkan dalam suatu berita acara sebagai dasar untuk Pembukuan HAT dalam buku tanah, pengakuan HAT, pemberian HAT; 11) Pembukuan Hak (Pasal 29-30), pembukuan dalam buku tanah serta pencatatannya pada surat ukur merupakan bukti bahwa hak yang bersangkutan beserta pemegang haknya dan bidang tanah yang diuraikan dalam surat ukur secara hukum telah terdaftar. Jika ada yang belum lengkap dibuat catatan yang akan dihapus bila, telah dilengkapi atau dalam jangka waktu 5 tahun tidakdk ada pengajuan gugatan ke pengadilan. Jika ada sengketa, maka akan dibuat catatan, yang akan hapus jika telah ada kesepakatan damai atau 90 hari setelah terima pemberitahuan tidak diajukan gugatan di pengadilan; 12) Penerbitan sertifikat (Pasal 31), dilakukan untuk kepentingan pemegang hak yang bersangkutan, jika ada catatan maka penerbitan akan ditangguhkan Individual di tanda tangani oleh Kepala kantor BPN, Massal oleh Kepala seksi pengukuran dan pendaftaran 
tanah atas nama kepala kantor BPN. Begitulah seharusnya proses legalisasi kepemilikan hak atas tanah yang dapat dilakukan masyarakat dan Pakualaman jika didasarkan pada Hukum Tanah Nasional yaitu UUPA.

\section{Tindak Lanjut Proses Pendaftaran Hak Atas Tanah Bekas Paku Alaman Ground Dari Kadipaten Paku Alaman Kepada Masyarakat di Kabupaten Kulon Progo}

Pengaturan kegiatan pendaftaran tanah yang terdapat dalam perundang undangan adalah, sebagai berikut: a. Pasal 19, Pasal 23, Pasal 32 serta Pasal 38 UUPA dan PMA Nomor 1/1966 untuk Hak Pakai atas Tanah Negara; b. Peraturan Pemerintah No. 10 Tahun 1961 tentang Peraturan Pendaftaran Tanah beserta peraturan pelaksananya sebagaimana telah diubah dengan Peraturan Pemerintah No. 24 Tahun 1997 tentang Pendaftaran Tanah; c. Peraturan Menteri Agraria/ Kepala Badan Pertanahan Nasional No. 3 Tahun 1997, tanggal 1 Oktober 1997, tentang Peraturan Pelaksanaa Peraturan Pemerintah Nomor 24 Tahun 1997 tentang Pendaftaran Tanah.

Dalam hukum pertanahan dikenal dua sistem pendaftaran tanah, yaitu: a. Registration of Titles. Registration of titles merupakan sistem pendaftaran hak. Dalam registration of titles, setiap pencatatan hak harus dibuktikan dengan suatu akta, tetapi dalam penyelenggaraan pendaftaran bukan aktanya yang didaftar, melainkan haknya yang diciptakan. C. Registration of Deeds. Regristration of deeds adalah sistem pendaftaran akta. Dalam system ini, akta merupakan data yuridis dan karenanya akta itulah yang didaftar Pejabat Pendaftaran Tanah (PPT). Pejabat Pendaftar Tanah bersifat pasif dan tidak melakukan pengujian atas kebenaran data yang disebut dalam akta yang didaftar.

Menurut Peraturan Pemerintah Nomor 10 Tahun 1961 sebagaimana telah diubah dengan Peraturan Pemerintah No. 24 Tahun 1997 tentang Pendaftaran Tanah, sistem pendaftaran tanah yang digunakan adalah sistem pendaftaran hak. Dalam sistem pendaftaran hak, orang yang tercatat dalam buku tanah merupakan pemegang hak atas tanah tersebut sampai dapat dibuktikan sebaliknya.

Sistem pendaftaran hak dapat diketahui dari adanya buku tanah sebagai dokumen yang memuat data yuridis dan data fisik yang dihimpun dan disajikan serta diterbitkannya sertifikat sebagai surat tanda bukti hak yang didaftar. Pembukuan dalam buku tanah serta pencatatannya pada surat ukurtersebut merupakan bukti bahwa hak yang bersangkutan 
beserta pemegang haknya dan bidang tanahnya yang diuraikan dalam surat ukur secara hukum telah didaftar. ${ }^{16}$

Berdasarkan wawancara dengan Pihak pakualaman, didapat beberapa informasi mengenai kebijakan pengelolaan pertanahan yang berhubungan dengan keberadaan lembaga Kewedanaan Hageng Punokawan "Wahono Sarto Kriyo", yaitu sebuah Kepala Lembaga Tata Pemerintahan Keraton berdasarkan Surat Keputusan Kawedanan Hageng Punokawan Wahono Sarto Kriyo Nomor 29/W dan Nomor K/81 tentang Pemberian Hak Guna Bangunan, Hak Pakai, Hak Ngindung dan Hak Magersari di atas tanah Kasultanan, dimana kebijakan tersebut menetapkan Sultan Ground dan Pakualaman Ground termasuk Crown Domain atau dapat juga disebut Sultanaat Groundd/Kagungan Dalem yang selanjutnya disebut "Sultan Ground" adalah tanah milik Kasultanan yang biasa diberikan dan dibebani hak, baik oleh pribumi dan hak-hak barat di atas tanah Keraton Ngayogyakarto Hadiningrat. Berdasarkan hasil identifikasi dan pengukuran kerjasamaantara Kantor Wilayah Badan Pertanahan Nasional Kabupaten Kulonprogo dan Pemerintah Daerah Kabupaten Kulonprogo pada Tahun 2016 didapat hasil penguasaan dan pemilikan tanah swapraja dan bekas swapraja yang telah didaftrakan pihak kadipaten Pakualaman kepada BPN kurang lebih sebanyak 200 Bidang tanah yang telah di daftarkan dari kurang lebih 330,620 Ha tanah milik Pakualaman di Kabupaten Kulonprogo. Luas tanah milik Kasultanan dan Kadipaten yang terdapat di Kabupaten Kulonprogo kurang lebih 5.128.950 Ha, sehingga masih memerlukan proses pendataan yang panjang oleh BPN dalam hal sertifikasi tanah milik Pakualaman dan Kasultanan DIY tersebut. ${ }^{17}$

Dalam menindaklanjuti proses pendaftaran tanah PAG di BPN Kabupaten Kulon Progo, maka pihak yang mewakili Kadipaten Pakualaman datang sendiri ke BPN Kabupaten Kulon Progo untuk memohonkan pendaftaran Hak Milik atas Tanah-tanah PAG di Kabupaten Kulon Progo, Kemudian BPN Kab. Kulon Progo akan meminta desa untuk membantu dengan mengirimkan data kepada BPN mengenai tanah-tanah yang mereka catat sebagai PAG. ${ }^{18}$

Setelah mendapatkan data dari desa maka BPN Kab.Kulon Progo akan melakukan pengecekan data yaitu mencocokkan nomor Legger dengan Peta tanah milik BPN Kab.Kulon Progo. Apabila keduanya cocok maka akan segera diproses hak milik atas tanahnya akan tetapi yang sulit adalah ketika tidak ada nomor leggernya sehingga badan

${ }^{16}$ Djoko Prakoso dan Budiman Adi Purwanto, Eksistensi Prona sebagai Pelaksanaan Mekanisme Fungsi Agraria, Ghalia Indonesia, Jakarta,1985, hlm. 22.

17 Wawancara dengan Bapak Sungkowo dari bagian HTPT BPN Kabupaten Kulonprogo.

${ }^{18}$ Ibid 
pertanahan harus melihat peta tanah satu persatu untuk mengetahui lokasi mana yang merupakan PAG untuk kemudian diterbitkan sertifikatnya.

\section{Penutup}

Berdasarkan uraian sebelumnya, maka hasil penelitian ini adalah pertama, proses konversi hak atas tanah Pakualaman Ground mengacu pada prosedur pendaftaran tanah secara sporadik yang tercantum tata caranya pada UUPA pasal 19 dan PP 24/1997 Pasal 1331. Kedua, dalam menindaklanjuti proses pendaftaran tanah PAG di BPN Kabupaten Kulon Progo, maka pihak yang mewakili Kadipaten Pakualaman datang sendiri ke BPN Kabupaten Kulon Progo untuk memohonkan pendaftaran Hak Milik atas Tanah-tanah PAG di Kabupaten Kulon Progo, Kemudian BPN Kab.Kulon Progo akan meminta desa untuk membantu dengan mengirimkan data kepada BPN mengenai tanah-tanah yang mereka catat sebagai PAG. Setelah mendapatkan data dari desa maka BPN Kab.Kulon Progo akan melakukan pengecekan data yaitu mencocokkan nomor Legger dengan Peta tanah milik BPN Kab.Kulon Progo. Apabila keduanya cocok maka akan segera diproses hak milik atas tanahnya akan tetapi yang sulit adalah ketika tidak ada nomor leggernya sehingga badan pertanahan harus melihat peta tanah satu persatu untuk mengetahui lokasi mana yang merupakan PAG. Peneliti menyarankan, pertama: segera diundangkan dan disahkannya PERDAIS khususnya dalam bidang Pertanahan. Membuat suatu sistem atau aplikasi menggunakan komputer yang dapat mempermudah kegiatan inventarisasi Tanah Kasultanan dan Kadipaten. Kedua, memberikan Edukasi terhadap Masyarakat umum mengenai pentingnya memiliki alat bukti Hak Atas Tanah walaupun tanah tersebut adalah tanah yang dipinjamkan atau diberikan oleh Raja.

\section{Daftar Pustaka}

\section{Buku}

Abu Daud Busroh, Ilmu Negara, Cetakan Pertama, Bumi Aksara, Jakarta, 1990

Abdurrahman, Beberapa Pemikiran Tentang Otonomi Daerah, Media Sarana Press, Jakarta, 1987

Achmad Roestandi, Responsi Filsafat Hukum, Armico-Bandung, 1992

Adnan Buyung Nasution, Arus Pemikiran Konstitusionalisme, Kata Hasta Pustaka, Jakarta, 2007

Arie Sukanti Hutagalung \& Markus Gunawan, Kewenangan Pemerintah di Bidang Pertanahan, Rajawali Pers, Jakarta, 2009 
B. Hestu Cipto Handoyo, Hukum Tata Negara, Kewarganegaraan dan Hak Asasi Manusia, Yogyakarta, Universitas Atma Jaya Yogyakarta, 2003

Bagir Manan, Menyongsong Fajar Otonomi Daerah, Pusat Studi Hukum Fakultas Hukum UII, Yogyakarta, 2001 Perjalanan Historis Pasal 18 UUD 1945, UNISKA, Jakarta, 1993

Buku Pedoman Penulisan Tugas Akhir (TESIS),Program Magister Kenotariatan,Universitas Islam Yogyakarta

Boer Mauna, Hukum Internasional Pengertian, Peranan dan Fungsi dalam Era Dinamika Global, PT Alumni, Bandung, 2005

Brian Z Tamanaha, On The Rule of Law, History, Polities, Theory, Cambridge University Press, Edisi Keempat, 2006

C.F.Strong, Modern Political Constitution: An Introduction to the Comparative Study of Their History and Eisting Form, The English Book Society and Sidgwick \& Jackson Limited, London, 1966

, Konstitusi-Konstitusi Politik Modern Kajian Tentang Sejarah \& Bentuk-bentuk Konstitusi Dunia, Nuansa dan Nusamedia, Bandung,2004

Cotterrell, Roger, The Politics of Fikih: A Critical Introduction to legal Philosophy, 2nd ed. London, LexisNexis, 2003

C. S. T, Kansil, Ilmu Negara (umum dan indonesia), Pradya Paramita, Jakarta, 2004

Djoko Prakoso dan Budiman Adi Purwanto, Eksistensi prona sebagai pelaksanaan mekanisme fungsi agraria, Ghalia Indonesia,Jakarta,1985

Edie Toet Hendratno, Negara Kesatuan, Desentralisasi, dan Federalisme, Graha Ilmu dan Universitas Pancasila Press,Jakarta,2009

F. Budi Hardiman, "Filsafat Modern Dari Machiavelli sampai Nietzsche', Gramedia Pustaka Utama, Jakarta, 2004

Fred Isjwara,Pengantar Ilmu Politik, Cetakan Kelima, Binacipta, Bandung, 1974

Huala Adolf, Aspek-aspek Negara dalam Hukum Internasional,Rajawali,Jakarta, 1991

Hans Kelsen, Teori Hukum Tentang Hukum dan Negara,diterjemahkan oleh Raisul Muttaqien,Nusamedia dan Nuansa,Bandung,2010

Ian McLeod, Legal Theory, Second Edition (New York : Palgrave Macmillan, 2003)

J. Wajong, Asas Dan Tujuan Pemerintah Daerah, Jambatan, Jakarta, 1975

Jacobus Peterviddya Solossa, Otonomi Khusus Papua Mengangkat Martabat Rakyat Papua di Dalam NKRI, Sinar Harapan, Jakarta, 2005

John Fich, Introduction to Legal Theory (London : Sweet \& Maxwell, 1974)

John Austin, The Province Of Jurisprudence, dalam Darji Darmodiharjo, Pokok-pokok Filsafat Hukum, Gramedia, Jakarta, 2004

Jawahir Thontowi dan Pranoto Iskandar,Hukum Internasional Kotemporer,Refika Aditama, Bandung, 2006 
Khudzaifah Dimyati, Teorisasi Hukum: Studi tentang Perkembangan Pemikiran Hukum di Indonesia 1945-1990, Cetakan keempat, MuhammadiyahUniversity Press, Surakarta,2005

Miriam Budiardjo, Dasar-dasar Ilmu Politik, Cetakan XIII, Gramedia Pustaka Utama, Jakarta, 1991

, Dasar-Dasar Ilmu Politik, Gramedia Pustaka Utama, Jakarta, 1998

M.Laica Marzuki, Berjalan-jalan Di Ranah Hukum, Sekertariat Jenderal dan Kepaniteraan Mahkamah Konstitusi RI, Jakarta,2006

M. Nasroen, Masalah Otonomi,J.B Wolters, Jakarta,1951

M. Ryaas Rasyid, Otonomi Daerah Dalam Negara Kesatuan, Yogyakarta: Pustaka Pelajar, 2002

M. Solly Lubis, Pergeseran Garis Politik dan Perundang-undangan Mengenai Pemerintah Daerah, Alumni, Bandung, 1990

Miftah Adhi Ikhsanto dan Wawan Mas'udi, Decentralized Governance: Sebagai Wujud Nyata dari Sistem Kekuasaan Kesejahteraa dan Demokrasi.Jurusan FISIPOL UGM, Yogyakarta,2011

Ni'matul Huda S.H.,M.Hum., Desentralisasi Asimetris, Nusa Media, Bandung,2014

Oemar Seno Adji, Peradilan Bebas, Negara Hukum, Penerbit Erlangga, Jakarta, 1980

Paulus Hadisuprapto, Ilmu Hukum dan Pendekatannya, disajikan dalam Diskusi Panel "Refleksi Pendidikan Tinggi Hukum “, Semarang 17 Januari 2006.

Ramlan Surbakti, Memahami Ilmu Politik ,Grassindo,Jakarta, 2010

R.M. Dworkin, ed., The Philosophy of Law (Oxford University Press, 1977), H.L.A. Hart, The Concept of Law, Oxford, Oxford University Press, 1982

R.Tresna, Bertamasya Ke Taman Ketatanegaraan, Penerbit Dibya,Bandung, Tanpa Tahun

Ronny Hanityo Soemitro, Metodologi Penelitian Hukum dan Jurimetri, Ghalia Indonesia, Jakarta, 1998

Sarjita, Pelaksanaan Urusan Pertanahan Dalam Era Otonomi Daerah (Keppres No. 34 Tahun 2003), Tugu Jogja Pustaka, Yogyakarta, 2005

Soedarisman P., Daerah Istimewa Yogyakarta, Gajah Mada University Press, Yogyakarta, 1984

Soerjono Soekanto, Pengantar Penelitian Hukum, UI Press, Jakarta, 1986

Srijanti dkk., Pendidikan Kewarganegraan Di Perguruan Tinggi Mengembangkan Etika Berwarga Negara, Salemba Empat, Jakarta, 2009

Soemantri M., Pengantar Perbandingan Antar Hukum Tata Negara, Rajawali, Jakarta. 1981

Tahrir Azhary, NegaraHukum, Suatu Study tentang Prinsip-Prinsipnya dilihat dari segi Hukum Islam, Implementasinya pada periode Negara Madinah dan Masa Kini, Edisi Kedua, Kencana, Jakarta, 2003 
Theo Huijbers, Filsafat Hukum Dalam Lintasan Sejarah, Cetakan ketujuh, Kanisius, 1993, Yogyakarta

Wahyudi Kumorotomo dan Ambar Widaningrum, Reformasi Aparatur Negara Ditinjau Kembali, Penerbit: Gava Media,Yogyakarta,2010.

\section{Disertasi}

Astim Riyanto, Aktualisasi Negara Kesatuan Setelah Perubahan Atas Pasal 18 UndangUndang Dasar Negara Republik Indonesia Tahun 1945, Disertasi Program Pascasarjana Universitas Padjadjaran, Bandung, 2006

\section{Jurnal}

Djohermansyah Djohan, Desentralisasi Asimetris Aceh, Jurnal Sekretariat RI No. 15, Februari 2010

Philippe Nonet \&Philip Selznich,Law and Society in Transitiopn:Toward Responsive Law,New York:Harper Colophon Books, 1978, dikutip dari Jurnal Hukum Progresif,Pencarian ,Pembebasan dan Pencerahan,Vol:1/Nomor1/April 2005, Program Doktor Ilmu Hukum Universitas Diponegoro, Semarang

Robert Endi Jaweng, "Kritik Terhadap Desentralisasi Indonesia", Jurnal Analisis, CSIS, Vol.40,Juni 2011

Sadu Wasistiono, Kajian Hubungan antara Pemerintah Pusat dengan Pemerintah Daerah (Tinjauan dari Sudut Pandang Manajemen Pemerintahan)", Jurnal Adminirtasi Pemerintahan Daerah, Volume I, Edisi Kedua 2004

Satjipto Rahardjo,"Hukum Progresif: Hukum yang Membebaskan. Jurnal Hukum Progresif'. Program Doktor Ilmu Hukum Univ. Diponegoro, Vol. 1/No. 1/April 2005

SoetandyoWignjosoebroto, "Positivisme dan Doktrin Positivisme dalam Ilmu Hukum dan Kritik-kritik terhadap Doktrin Ini" Materi Kuliah Teori Hukum Program Doktor Ilmu Hukum UII, 2007

Wasisto Raharjo Jati, Politik Agraria Di Yogyakarta : Identitas Partrimonial \& Dualisme Hukum Agraria (Politic Of Agrarian In Yogyakarta; Patrimonial Identity 7 Agrarian Law Dualism) Jurnal Legislasi Indonesia Vol. 11 No. 1 - Maret 2014.

\section{Makalah}

Bayu Dardias Kurniadi, Desentralisasi Asimetris Di Indonesia, 2012

Cornelis Lay, Desentralisasi Asimetris Bagi Indonesia, yogyakarta, Januari 2010

Djohermansyah Djohan, Desentralisasi Asimetris dan Masa Depannya di Indonesia: Kasus Aceh dan Papua, Manado, 15 Agustus 2007

\section{Undang - Undang}

Undang-Undang Dasar Negara Republik Indonesia Tahun 1945

Undang - Undang Nomor 5 Tahun 1960 tentang Peraturan Dasar Pokok - Pokok Agraria

Undang - Undang Nomor. 3 Tahun 1950 tentang Pembentukan Daerah Istimewa Yogyakarta 
Undang - Undang Nomor 32 Tahun 2004 tentang Pemerintahan Daerah

Undang - Undang Nomor 13 Tahun 2014 tentang Keistimewaan Daerah Istimewa Yogyakarta

\section{Internet}

http:www.kulonprogokab.go.id

http://dppka.jogjaprov.go.id/

http://rumputhitam.blogspot.co.id 